\title{
Accounting
}

\section{Bank's brand, social influence, and its impact on the decision on using mobile banking services of individual} customers: An empirical study

\section{Vo Thi Phuong Lan ${ }^{a^{*}}$ and Nguyen Thanh Gianga}

\begin{tabular}{l}
${ }^{a}$ Academy of Finance, Hanoi, Vietnam. \\
\hline C H R O N I C L E \\
\hline Article history: \\
Received: September 28, 2020 \\
Received in revised format: \\
December 282020 \\
Accepted: December 28, 2020 \\
Available online: \\
January 15, 2021 \\
\hline Keywords: \\
Brand \\
Risk management \\
Social influence \\
Bank
\end{tabular}

\section{A B S T R A C T}

In the context of fintech and industrial revolution 4.0, the banking system worldwide has significantly developed mobile banking services at a great pace in order to promote economic performance. The aim of this analysis is to estimate factors that impact on the customers' use of mobile-banking services in the typical case in Vietnam nowadays. Using a sample data of 420 questionnaires covering in 2020 , the results indicate that brand and social influence have greatly impacted on the customers' use of mobile-banking services. A greater bank's brand and social influence is positively related to a greater the customers' use of mobile-banking services. In addition, transaction risk has a negative impact on decisions to use mobile-banking services. Vietnam should enhance the risk management in the banking sector in order to maintain sustainable development in the long run.

(C) 2021 by the authors; licensee Growing Science, Canada

\section{Introduction}

The banking sector is an important channel through which financial development impacts on economic growth and sustainable development in both developed and developing economies (Tran \& Tran, 2020). To contribute to the development of the banking system, mobile-banking services have significantly created great strides. In addition, mobile-banking services have predominantly contributed a great diversification regarding the types of services in banking systems in general and commercial banks in particular, and are an indispensable service in the process of national integration in each country (Ai \& Thanh, 2020; Ai \& Tan, 2020). According to the development of revolution 4.0, the increase in the number of internet users has totally created a wealth of opportunities for individuals and organizations, and especially financial institutions. Indeed, digital banking and blockchain technologies are changing daily and supporting our lives while the impact of the revolution 4.0 on the banking sector has also made risks and more vulnerable to the banks in the form of system security (Dao et al., 2018; Hussain at el., 2020; Nguyen \& Ao, 2020). In addition, banks are likely to implement internet tools and technology to capture its advantages regarding revolution 4.0. Further, mobile banking uses internet tools as a channel to provide services, for example, money transfers, and bill payment. As suggested in Hien (2020), mobile banking will exactly enhance the bank's growth profits by reducing operating costs, fixed costs, and other extra costs. As suggested in Li et al. (2020), Nguyen and Nguyen (2017), Do (2013) the cost of a transaction that does not involve cash at a bank is relatively higher than a similar transaction through electronic banking.

* Corresponding author

E-mail address: n8835293@gmail.com (V. T. P. Lan) 
Additionally, through the internet, a bank can easily improve its marketing and contact with its customers due to the limitation of operation time in dealing at banks. Another suggestion to the mobile banking, transactions are likely to be available and can be guided through the service sign board provided by the bank. Regarding the benefits of customers, mobile banking also offers convenience with affordable fees. In addition, customers in a bank can make all transactions at any time without having to spend time waiting at the bank.

In the trends of fintech and industrial revolution 4.0, online payment via electronic banking such as internet banking, mobile banking, web banking has significantly grown at a great pace in recent years. However, it has been predominantly booming when the number of users have a great purchase on goods and services, especially through technological platforms (Nguyen \& Nguyen, 2017; Dao et al., 2020; Hien, 2020). The number of users of these kinds has been increasing in Vietnam. In fact, a population of 96 million people in 2019, approximately $63 \%$ of people have been using smartphones and easy to access the internet with an average of two hours per day. Therefore, online shopping has been accounting for $61 \%$. Further, a very strong growth rate of the bank card market also has indicated that the trend of non-cash consumption exists in Vietnam and contributed to the growth of mobile payment services.

Foreseeing this trend of fintech development and industrial revolution 4.0, the bank has constantly improved its products and services to attract more customers. In addition, mobile-banking service has been expanded in Vietnam in recent years. In this study, the purpose of this analysis is to examine what main factors affect the customers' use of mobile-banking services as a typical evidence in Vietnam nowadays. It hopes that this research will show the development of mobile-banking services in the banking system in a developing country in Asia.

\section{Theoretical framework}

\subsection{Mobile-banking and Its Theory}

Mobile banking has been developed in financial institutions nowadays, as a form of conducting financial and banking transactions through electronic means. More specifically, mobile banking refers to the use of a mobile device in the transactions of financial products or services. The services are provided by banks, and clients are able to see their balances, bank statements. In addition, mobile-banking has been allowing customers to perform online transactions through mobile phones or other personal assistive devices. Thereby, customers can access at any time in the financial services or products without having to go to the bank. In recent years, developing economies' banking industry has been a pioneer in joining the $4^{\text {th }}$ industrial revolution. Along with the development of technology, the development of the banking sector, especially towards mobile-banking is such an inevitable trend not only today but also in the future. In general, mobile-banking is known as a type of commerce in terms of finance and banking with the help of information technology and it allows customers to remotely access information.

To discuss more customers' behavior, this study tries to explain that the Technology Acceptance Model (TAM) is good in this case in order to explain and predict the acceptance of a new technology. More specifically, TAM is widely tested in the context of information technology, and widely considered as a good predictive model. In most cases, the acceptance of this model is significantly correlated with the use of technology. In addition, the TAM model was originally created to estimate IT adoption in companies or banks. In which, external factors that affect a person's beliefs about accepting products or services. External factors often arise from two sources, for example, social influencing and cognitive processes, and personal experience gathering. Further, perceived usefulness is the degree to which a person believes that using a particular system improves their own performance (Davis et al., 1989). It is important to note that attitude is a positive or negative feeling about the implementation of the target behavior (Fishbein \& Ajzen, 1975) as an important factor affecting the success of the system.

\subsection{Research Theory}

As suggested in Picoto and Pinto (2020) on a study of the adoption and use of mobile banking in different countries as Brazil, India, UK, and the United States of America. Using Hofstedés theory with five dimensions, for example, power distance, uncertainty avoidance, masculinity femininity, individualism collectivism, and long or short run orientation, Picoto and Pinto (2020) indicate that both power distance and long run orientation are becoming more important dimensions that affect the correlation between the intention to use mobile banking and its real use. In addition, Thusi and Maduku (2020) indicate that performance expectancy, habit, and perceived risk are significantly related to the intention to adopt mobile banking in the case of South Africa.

According to Ho et al. (2020), the share of mobile services has been strongly developing in Asian economies with a great opportunity to contribute value-added services. Using the TAM model, and the decomposed theory of planned behavior model, Ho et al. (2020) discuss the adoption of mobile banking in Taiwan and Vietnam. Results indicate that subjective norms have an effect on the intention to adopt, and three forms of mobile banking such as compatibility, perceived risk and usefulness are found to have indirect impact on the intention to adopt mobile banking. Towards the past, this study was also analyzed by the model according to Theory of Reasonable Action by Fishbein and Ajzen (1975), The Theory of Intended Behavior of Ajzen (1991), Technology Acceptance Model by Davis et al. (1989). In addition, empirical studies on the decision to use mobile- 
banking services have been studied by authors such as Ho et al. (2020); Picoto et al. (2020). Additionally, Jebarajakirthy and Shankar (2020) indicate that access, benefit, and transaction convenience, post-benefit convenience have an important impact on mobile banking adoption intention. Therefore, convenience plays a major role in mobile commerce adoption intention. In addition, other factors may be considered as (1) bank brand, and security, (2) expected efficiency and social influence, (3) perceived risk. In order to solve the purpose of this study and according to the discussion above, we propose six factors as follows:

$\mathrm{H}_{1}$ : The bank brand has a positive impact on the individual customers' decision to use e-banking services in Vietnam.

$\mathrm{H}_{2}$ : Social influence has a positive impact on the individual customers' decision to use e-banking services in Vietnam.

$\mathrm{H}_{3}$ : Security has a positive impact on the individual customers' decision to use mobile-banking services in Vietnam.

$\mathrm{H}_{4}$ : The expected efficiency, and perceived preference have a positive impact on the individual customers' decision to use ebanking services in Vietnam.

$\mathrm{H}_{5}$ : Perceived risk in transaction has a negative impact on the individual customers' decision to use e-banking services in Vietnam.

\section{Research Results}

\subsection{Data description}

The customer is one who has a bank account. Customer is the bank's depositor who sends their financial resources, banking facilities, for storage and fruiting. In this study, we collect 450 questionnaires from customers, after revising the missing, we finalize and conclude 420 satisfied questionnaires. The valid questionnaires were shown in Fig. 1 below:

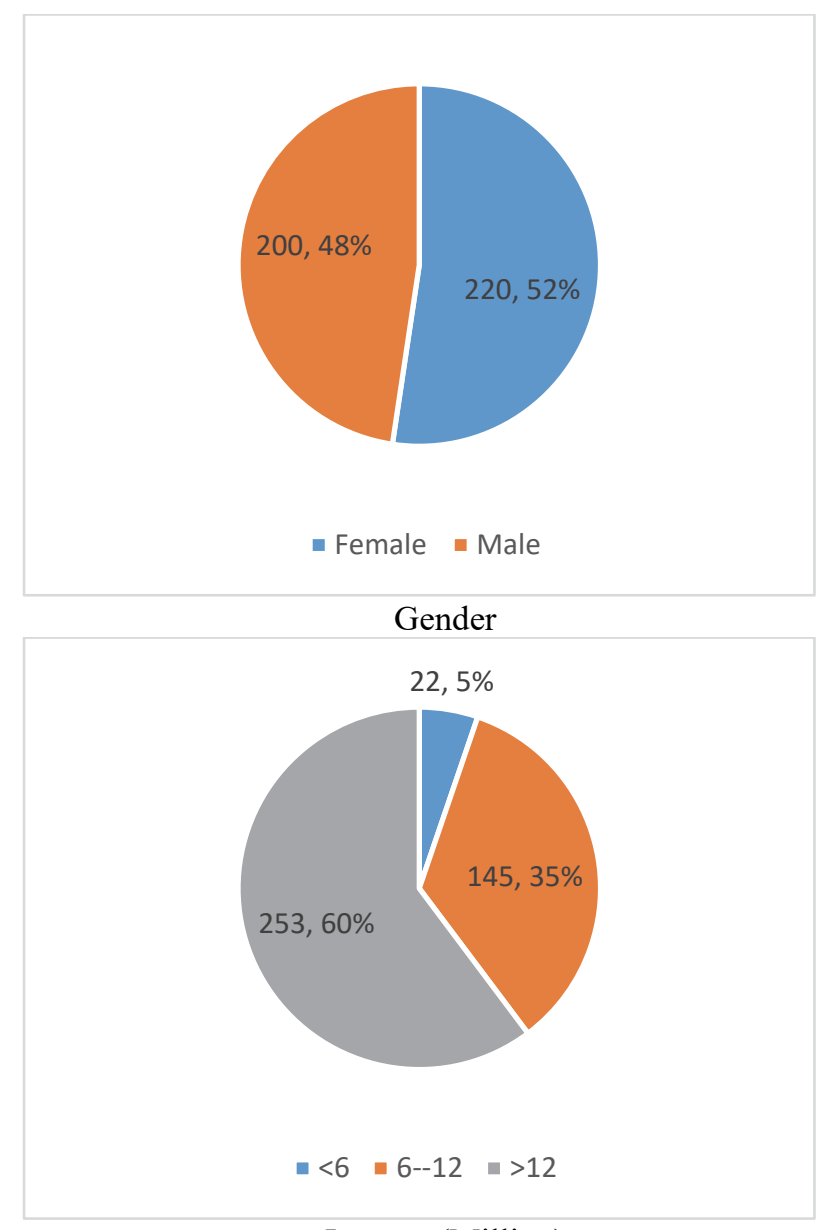

Income (Million)

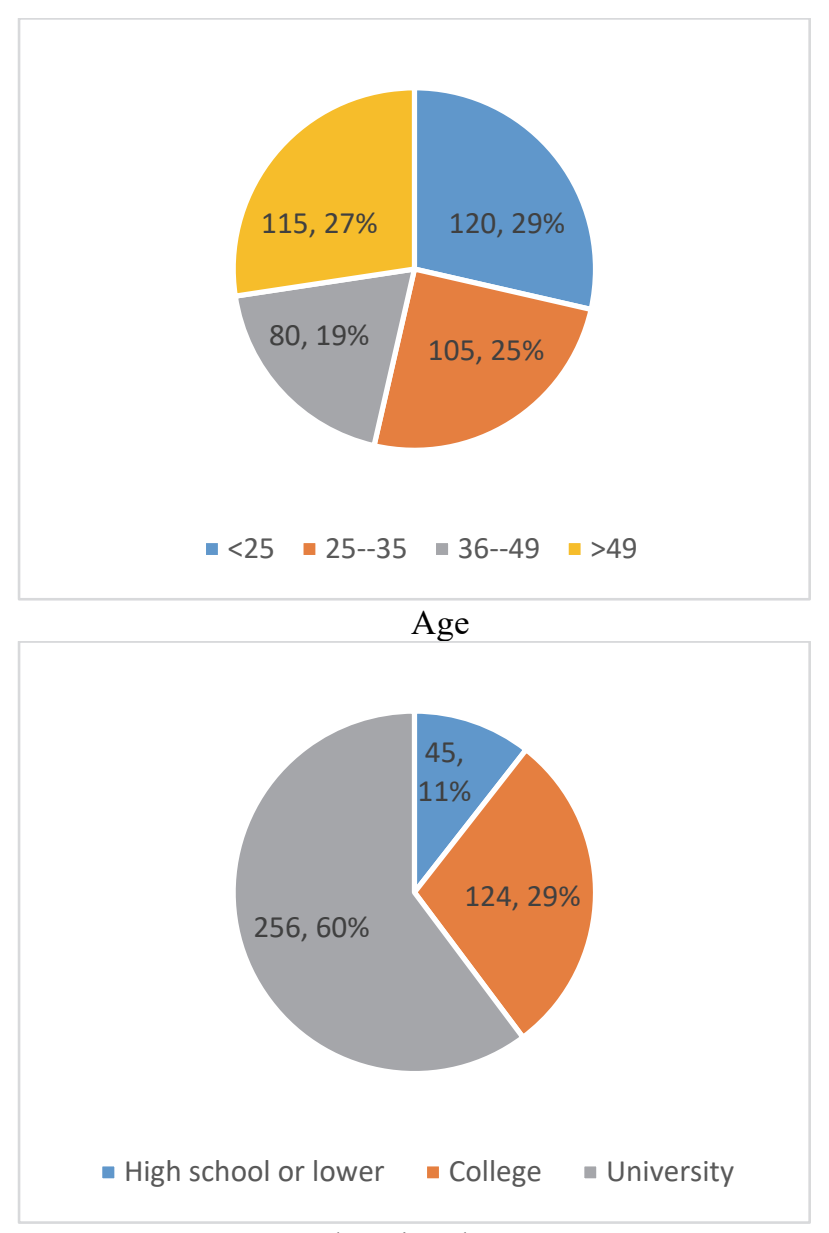

Educational Degree

Fig. 1. Descriptive Statistics

Source: Analysis of the authors 


\subsection{Reliability of the scale}

In order to test the reliability of the scale, we use Cronbach's alpha. In this case, observed variables with total correlation coefficients of less than 0.3 will be rejected (Picoto \&Pinto, 2020; Ho et al., 2020). After analyzing Cronbach's alpha, the variable of brand was eliminated due to its total correlation being less than 0.3 . The second test results, the above scales all had quite high Cronbach's Alpha coefficients (greater than 0.7), the total correlation coefficient was greater than 0.3 (see Table 1), therefore, it was used for the next EFA procedure (Sinha \& Mukherjee, 2020).

\section{Table 1}

Cronbach's alpha and total correlation coefficient

\begin{tabular}{|c|c|c|c|c|}
\hline Variable name & Symbol & Number of observed variables & Cronbach's & Minimum total correlation \\
\hline Bank brand & BRAND & 4 & 0.756 & 0.505 \\
\hline Social influence & SOCIAL & 4 & 0.821 & 0.574 \\
\hline Security & SECURITY & 4 & 0.881 & 0.716 \\
\hline Expected efficiency & EXPECT & 4 & 0.896 & 0.700 \\
\hline Perceived risk in transaction & RISK & 4 & 0.838 & 0.550 \\
\hline Perceived preference & INTEREST & 5 & 0.855 & 0.714 \\
\hline Decision to use e-banking & DECISION & 4 & 0.782 & 0.568 \\
\hline
\end{tabular}

Source: Analysis of the authors

\subsection{Evaluate the value of the scale}

\section{Table 2}

\section{Explorer Factor Analysis (EFA)}

\begin{tabular}{|c|c|c|c|c|c|c|}
\hline \multirow[t]{2}{*}{ Items } & \multicolumn{6}{|c|}{ Factor loading } \\
\hline & 1 & 2 & 3 & 4 & 5 & 6 \\
\hline EXPECT1 & 0.886 & & & & & \\
\hline EXPECT2 & 0.865 & & & & & \\
\hline EXPECT3 & 0.854 & & & & & \\
\hline EXPECT4 & 0.852 & & & & & \\
\hline RISK1 & & 0.854 & & & & \\
\hline RISK2 & & 0.843 & & & & \\
\hline RISK3 & & 0.812 & & & & \\
\hline RISK5 & & 0.767 & & & & \\
\hline SECURITY 1 & & & 0.865 & & & \\
\hline SECURITY 2 & & & 0.856 & & & \\
\hline SECURITY 3 & & & 0.843 & & & \\
\hline SECURITY 4 & & & 0.821 & & & \\
\hline SOCIAL1 & & & & 0.865 & & \\
\hline SOCIAL2 & & & & 0.845 & & \\
\hline SOCIAL3 & & & & 0.832 & & \\
\hline SOCIAL4 & & & & 0.721 & & \\
\hline INTEREST1 & & & & & 0.887 & \\
\hline INTEREST3 & & & & & 0.876 & \\
\hline INTEREST2 & & & & & 0.864 & \\
\hline INTEREST3 & & & & & 0.823 & \\
\hline INTEREST2 & & & & & 0.812 & \\
\hline BRAND1 & & & & & & 0.789 \\
\hline BRAND2 & & & & & & 0.787 \\
\hline BRAND3 & & & & & & 0.756 \\
\hline BRAND4 & & & & & & 0.734 \\
\hline Eigenvalue & 3.65 & 3.23 & 2.78 & 2.45 & 2.43 & 2.12 \\
\hline Extraction variance \% & 14.56 & 13.23 & 11.56 & 10.42 & 9.14 & 8.65 \\
\hline Cumulative variance & 14.56 & 27.79 & 39.35 & 49.77 & 58.91 & 67.56 \\
\hline
\end{tabular}

Source: Analysis of the authors

Table 3 indicates the Explorer factor analysis (EFA), it is evident that this value is appropriate due to KMO in the range of 0.5 and 1. As suggested in Picoto and Pinto (2020); Ho et al. (2020) who believe that factor loading which is greater than 0.5 and is considered to be practical significant. Accordingly, the decision to use mobile-banking of individual customers has enough requirements for reliability. Therefore, all observed variables of this scale were further evaluated by EFA. In addition, Eigenvalues values were greater than 1, the extracted variance is $67.56 \%$ (greater than $50 \%$ ) satisfied the requirements. 


\subsection{Correlation analysis}

A correlation matrix is a table indicating correlation coefficients between variables. Table 3 shows that the Pearson correlation coefficients between the variables and the significance of each coefficient are 0.8 and less. The significance of the coefficients was very small (less than 0.05 ), so the correlation coefficients were statistically significant.

Table 3

Results of correlation analysis

\begin{tabular}{|c|c|c|c|c|c|c|c|c|}
\hline & & BRAND & SOCIAL & SECURITY & EXPECT & RISK & INTEREST & DECISION \\
\hline \multirow[t]{3}{*}{ BRAND } & Pearson Correlation & 1 & $0.66 * *$ & $-0.56 * *$ & $0.21 * *$ & -0.21 & 0.07 & $0.67 * *$ \\
\hline & Sig. (2-tailed) & & 0.000 & 0.000 & 0.001 & 0.836 & 0.263 & 0.000 \\
\hline & $\mathrm{N}$ & 420 & 420 & 420 & 420 & 420 & 420 & 420 \\
\hline \multirow[t]{3}{*}{ SOCIAL } & Pearson Correlation & $0.62 * *$ & 1 & $-0.58 * *$ & $0.16^{* *}$ & -0.04 & -0.034 & $0.69 * *$ \\
\hline & Sig. (2-tailed) & 0.000 & & 0.100 & 0.020 & 0.030 & 0.000 & 0.000 \\
\hline & $\mathrm{N}$ & 420 & 420 & 420 & 420 & 420 & 420 & 420 \\
\hline \multirow[t]{3}{*}{ SECURITY } & Pearson Correlation & $-0.65 * *$ & $-0.54 * *$ & 1 & -0.08 & -0.032 & -0.045 & $-0.623 * *$ \\
\hline & Sig. (2-tailed) & 0.000 & 0.000 & & 0.020 & 0.230 & 0.023 & 0.001 \\
\hline & $\mathrm{N}$ & 420 & 420 & 420 & 420 & 420 & 420 & 420 \\
\hline \multirow[t]{3}{*}{ EXPECT } & Pearson Correlation & $0.145^{* *}$ & $0.156 * *$ & -0.067 & 1 & $0.268 * *$ & $-0.34 * *$ & $0.25 * *$ \\
\hline & Sig. (2-tailed) & 0.000 & 0.322 & 0.023 & & 0.000 & 0.000 & 0.000 \\
\hline & $\mathrm{N}$ & 420 & 420 & 420 & 420 & 420 & 420 & 420 \\
\hline \multirow[t]{3}{*}{ RISK } & Pearson Correlation & -0.034 & -0.023 & -0.056 & $0.24 * *$ & 1 & 0.034 & $0.133^{*}$ \\
\hline & Sig. (2-tailed) & 0.000 & 0.322 & 0.023 & 0.000 & & 0.000 & 0.322 \\
\hline & $\mathrm{N}$ & 420 & 420 & 420 & 420 & 420 & 420 & 420 \\
\hline \multirow[t]{3}{*}{ INTEREST } & Pearson Correlation & 0.034 & -0.045 & -0.066 & $-0.56 * *$ & 0.076 & 1 & 0.054 \\
\hline & Sig. (2-tailed) & 0.000 & 0.322 & 0.023 & 0.000 & 0.000 & & 0.000 \\
\hline & $\mathrm{N}$ & 420 & 420 & 420 & 420 & 420 & 420 & 420 \\
\hline \multirow[t]{3}{*}{ DECISION } & Pearson Correlation & $0.41 * *$ & $0.56 * *$ & $-0.57 * *$ & $0.44 * *$ & $0.66^{*}$ & 0.33 & 1 \\
\hline & Sig. (2-tailed) & 0.550 & 0.45 & 0.033 & 0.67 & 0.09 & 0.000 & \\
\hline & $\mathrm{N}$ & 420 & 420 & 420 & 420 & 420 & 420 & 420 \\
\hline
\end{tabular}

\subsection{Regression analysis}

Table 4

Regression analysis

\begin{tabular}{|c|c|c|c|c|c|c|c|c|}
\hline & \multirow{2}{*}{ Variables } & \multicolumn{2}{|c|}{ Unstandardized coefficients } & \multirow{2}{*}{$\begin{array}{c}\text { Standardized } \\
\text { Beta }\end{array}$} & \multirow{2}{*}{$\mathrm{t}$} & \multirow{2}{*}{ Sig. } & \multicolumn{2}{|c|}{ Coefficient of multicolinearity } \\
\hline & & B & Standard & & & & Tolerance & VIF \\
\hline \multirow{7}{*}{1} & (Constant) & 1.656 & 0.212 & & 5.340 & 0.000 & 0.535 & 1.869 \\
\hline & BRAND & 0.215 & 0.034 & 0.211 & 4.424 & 0.000 & 0.653 & 1.531 \\
\hline & SOCIAL & 0.365 & 0.054 & 0.334 & 6.323 & 0.000 & 0.623 & 1.488 \\
\hline & SECURITY & -0.323 & 0.032 & -0.223 & -1.323 & 0.340 & 0.545 & 1.834 \\
\hline & EXPECT & 0.165 & 0.011 & 0.112 & 1.343 & 0.331 & 0.632 & 1.582 \\
\hline & RISK & 0.176 & 0.022 & -0.023 & -3.232 & 0.000 & 0.545 & 1.834 \\
\hline & INTEREST & 0.033 & 0.056 & 0.032 & 1.211 & 0.312 & 0.656 & 1.524 \\
\hline
\end{tabular}

Dependent variable: DECISION Adjusted R2: 0.434 Statistical F (ANOVA): 78.232 Level of significance (Sig.): 0.000

Table 4 indicates that regression results regarding decision to adopt mobile banking in the bank in the case of Vietnam. Firstly, to test the phenomenon of multicollinearity, we consider the Variance Inflation Factor (VIF), in this case, the Variance Inflation Factor of variables is less than 10, indicating a multicollinearity phenomenon cannot be present. Further, Table 5 also depicts that adjusted $\mathrm{R}^{2}$ is 0.434 , indicating that $43.4 \%$ variation of decision to use mobile-banking is explained by the variation of all independent variables. In addition, $\mathrm{F}$ value is significant for Sig. $=0.000$, indicating that the linear regression model is appropriate.

\section{Discussion}

\subsection{Bank brand}

The bank's image has the great impact on the decision to use mobile-banking in the case of Vietnam with the coefficient of the regression results is 0.211 , positive and significant. It means that the banking sector in Vietnam should continue to enhance its image in order to successfully achieve the business goals. In fact, Vietnamese banking sector consists of a combination of state, joint stock, and foreign banks. In recent years, foreign banks with greater performance and technological level are more likely to construct its brand and make a fierce competition in Vietnam's market. Accordingly, it is necessary to deploy diversified, 
particularly user-friendly products for individual customers in order to develop a good impression on local banks. Additionally, promotion programs should be suitable based on the culture and habits of each bank to achieve high efficiency.

\subsection{Social influence}

Table 5 indicates that the coefficient of the regression results is 0.334 , positive and significant, meaning that this effect is strongest. A 1 increase in social influence is significantly correlated with 0.334 increase in the decision to use mobile-banking in the case of Vietnam. More explanation about this finding, nowadays, the popularity of new devices and technologies such as mobile phones, internet, broadcast has gradually dominated the living conditions and habits of people not only in Vietnam, also the global. In fact, information and communication devices have greatly contributed and changed human being's lives, exchange knowledge, and business. According to the development of revolution 4.0, the increase in the number of internet users has totally created a wealth of opportunities for individuals and organizations, and especially financial institutions, providing good service is also a way to make a good impression on customers. Therefore, the bank's leaders can introduce and promote the type of mobile-banking service to many potential consumers through the above organizations and individuals, making customers become closer to each other, and be familiar with this concept. In addition, the fourth industrial revolution is already having massive impacts on business, society, and banking sector worldwide, therefore, the bank needs to improve service quality, assist in solving problems that customers encounter during use, helping customers to have peace of mind in their use. To reach this trend, the banking industry in Vietnam needs to experience the effects of the industrial revolution 4.0 in order to maximize their profits.

\subsection{Other factors}

Table 5 indicates that the coefficient of the regression results of perceived risk in transactions is negative and significant, meaning that this effect is negative in the relationship between perceived risk in transactions and the decision to use mobilebanking in the case of Vietnam. As a result, transaction risk issues have a negative impact on decisions to use mobile-banking services, indicating that a damage on decisions to use mobile-banking services from transaction risk can be present. In fact, building a mobile banking system, banks should pay attention to data security and integrity, and risks. Mobile-banking products always have high transaction risks, customers who transact through this channel are often less patient with the shortcomings of the bank. To improve the safety of banking transactions, the Vietnam banking sector needs to strictly manage the process of system declaration and inspection. For example, it is necessary to instruct staff to guide customers specifically and clearly about the risks and benefits of customers when providing services to customers, should be fully informed and accurate to the customers about their rights, obligations and responsibilities and the bank for matters related to online transactions, especially those that may arise from error handling and breaching system security. This evidence can be explained by study of Li et al. (2020), who indicate that four major factors that can drive customer satisfaction towards e-banking are cloud services, security, e-learning, and service quality. Similarly, Thusi and Maduku (2020) indicate that perceived risk is also significantly related to the intention to adopt mobile banking in the case of South Africa. In this study, other factors as Expected efficiency, security, and particularly perceived preference do not impact on the decision to use mobile-banking.

\section{Conclusions}

In the backdrop of fintech and industrial revolution 4.0, online payment via electronic banking such as internet banking, mobile banking, web banking has significantly grown at a great pace in recent years. The aim of this analysis is to examine main factors that impact on the customers' use of mobile-banking services as a typical evidence in Vietnam nowadays. Using a sample data of 420 questionnaires in Vietnam covering in 2020, the results indicate that brand and social influence have greatly impacted on the customers' use of mobile-banking services. Furthermore, transaction risk has a negative impact on decisions to use mobile-banking services, indicating that a damage on decisions to use mobile-banking services from transaction risk can be

present. Vietnam should enhance the risk management in the banking sector in order to maintain sustainable development in the long run.

\section{References}

Ajzen, I. (1980). From intentions to action: a theory of planned behavior. Berlin and New York: Springer-Verlag. Ajzen, I. (1991). The theory of planned behavior. Organizational Behavior and Human Decision Processes, 50(2), 179-211.

Ai, T.H., \& Thanh, D.K. (2020). Factors affecting brand strength within Vietnamese commercial banks. Industry and Trade Magazine. Available at https://tapchicongthuong.vn/bai-viet/cac-yeu-to-anh-huong-den-suc-manh-thuong-hieu-trong-noibo-cac-ngan-hang-thuong-mai-viet-nam-67994.htm

Ai, T.H., \& Tan, C.H. (2020). Factors affecting on individual customers when accepting Mobile banking services in Ho Chi Minh City. Industry and Trade Magazine. Available at http://tapchicongthuong.vn/bai-viet/cac-yeu-to-anh-huong-denkhach-hang-ca-nhan-khi-chap-nhan-dich-vu-mobile-banking-tai-thanh-pho-ho-chi-minh-76111.htm 
Dao, L.K.O., Nguyen, T.Y., Hussain, S., \& Nguyen, V.C. (2020). Factors affecting non-performing loans of commercial banks: The role of bank performance and credit growth. Banks and Bank Systems, 15(3), 44-54. http://dx.doi.org/10.21511/bbs.15(3).2020.05

Dao, M.H., Nguyen, T.T., Dang, T.H., \& Nguyen, T.L.T. (2018). Factors affecting the decision to use fintech services in payment activities of individual customers in Vietnam. Banking Science and Training Review, 194(7). http://210.245.26.173:6788/tapchi/08.2018/system/archivedate

Do, T.N.N. (2013). Study on factors affecting the acceptance of BIDV E-banking service by individual customers at BIDV Da Nang branch. Master Thesis. Available at http://tailieuso.udn.vn/bitstream/TTHL_125/7890/2/DoThiNhuNgan.TT.pdf

Davis, F. D., Bagozzi, R. P., \& Warshaw, P. R. (1989). User acceptance of computer technology: a comparison of two theoretical models. Management science, 35(8), 982-1003..

Fishbein, M., \& Ajzen, I. (1975). Belief, attitude, intention, and behavior. MA: Addison- Wesley.

Jebarajakirthy, C., \& Shankar, A. (2020). Impact of online convenience on mobile banking adoption intention: A moderated mediation approach. Journal of Retailing and Consumer Services, 58, 102323.

Hien, P.T.T. (2020). Factors affecting the individual customers' intention to use mobile banking services at Agribank Mang Thit District, Vinh Long Province. Review of Finance. Retrieved from http://tapchitaichinh.vn/tai-chinh-kinh-doanh/cac-yeu-toanh-huong-den-y-dinh-su-dung-dich-vu-mobile-banking-cua-khach-hang-ca-nhan-tai-agribank-huyen-mang-thit-tinh-vinhlong-326639.html

Ho, J. C., Wu, C. G., Lee, C. S., \& Pham, T. T. T. (2020). Factors affecting the behavioral intention to adopt mobile banking: An international comparison. Technology in Society, 63, 101360.

Hussain, S., Quddus, A., Tien, P.P., Rafiq, M., Pavelková, D. (2020). The moderating role of firm size and interest rate in capital structure of the firms: Selected sample from sugar sector of Pakistan. Investment Management and Financial Innovations, 17(4), 341-355. http://dx.doi.org/10.21511/imfi.17(4).2020.29

Li, F., Lu, H., Hou, M., Cui, K., \& Darbandi, M. Customer satisfaction with bank services: The role of cloud services, security, e-learning and service quality. Technology in Society, 64, 101487.

Nguyen, N.L., \& Nguyen, T.T.L. (2017). Regarding commercial bank selection decisions of individual customers. Review of Finance. Available at http:/tapchitaichinh.vn/kinh-te-vi-mo/ve-quyet-dinh-lua-chon-ngan-hang-thuong-mai-cua-khachhang-ca-nhan-129215.html

Nguyen, V.C., \& Ao, T.H. (2020). The Reaction of Vietnam's Generation Z to Online TV Advertising. Journal of Asian Finance, Economics and Business, 7(5), 177-184.

Picoto, W., \& Pinto, I. (2020). Cultural impact on mobile banking use - A multi-method approach. Journal of Business Research. Available online 29 October 2020. https://doi.org/10.1016/j.jbusres.2020.10.024

Sinha, S., \& Mukherjee, S. (2020). Sales strategies of banks: An empirical study of select private sector banks in India. Journal of Critical Reviews, 7(2), 62-66. doi: 10.31838/jcr.07.02.14

Thusi, P. and Maduku. D.K. (2020). South African millennials' acceptance and use of retail mobile banking apps: An integrated perspective. Computers in Human Behavior, Volume 111, October 2020, 106405. https://doi.org/10.1016/j.chb.2020.106405.

Tran, Q.T., \& Tran, N.A.T. (2020). Applying the CAMEL model to assess performance of commercial banks: empirical evidence from Vietnam. Banks and Bank Systems, 15(2), 167-176. doi: http://dx.doi.org/10.21511/bbs.15(2).2020.15 
(C) 2021 by the authors; licensee Growing Science, Canada. This is an open access article distributed under the terms and conditions of the Creative Commons Attribution (CC-BY) license (http://creativecommons.org/licenses/by/4.0/). 